Article

\title{
Impact of Industrial Production, Dam Construction, and Agriculture on the Z-IBI in River Ecosystems: A Case Study of the Wanan River Basin in China
}

\author{
Na Yao ${ }^{1}$, Bing Feng ${ }^{1, *}$, Meng Zhang ${ }^{1, *}$, Liang $\mathrm{He}^{2}$, Huan Zhang ${ }^{3}$ and Zugen Liu ${ }^{1}$ \\ 1 Jiangxi Academy of Environmental Sciences, Nanchang 330039, China; yn08192021@163.com (N.Y.); \\ lzg20212021@163.com (Z.L.) \\ 2 Key Laboratory of Poyang Lake Environment and Resource Utilization, Ministry of Education, \\ Nanchang University, Nanchang 330031, China; lianghe@ncu.edu.cn \\ 3 School of Life Science, Nanchang University, Nanchang, 330031, China; huanzhang@ncu.edu.cn \\ * Correspondence: bfeng2015@163.com (B.F.); tomdeshiye@126.com (M.Z.)
}

Citation: Yao, N.; Feng, B.; Zhang,

M.; He, L.; Zhang, H.; Liu, Z. Impact of Industrial Production, Dam

Construction, and Agriculture on the Z-IBI in River Ecosystems: A Case Study of the Wanan River Basin in China. Water 2021, 13, 123.

https://doi.org/10.3390/w13020123

Received: 23 November 2020 Accepted: 29 December 2020 Published: 7 January 2021

Publisher's Note: MDPI stays neutral with regard to jurisdictional clai$\mathrm{ms}$ in published maps and institutional affiliations.

Copyright: (C) 2021 by the authors. Licensee MDPI, Basel, Switzerland. This article is an open access article distributed under the terms and conditions of the Creative Commons Attribution (CC BY) license (https:// creativecommons.org/licenses/by/ $4.0 /)$.

\begin{abstract}
Industrial activity, dam construction, and agriculture-while important for socioeconomic progress-can severely damage the natural environment. To evaluate the effects of these human activities on the bio-integrity of riverine ecosystems, we examined the Wanan reach of the Ganjiang River (Wanan River basin), which contains the river's largest reservoir. On the basis of 20 attributes of zooplankton, we constructed a zooplankton index of bio-integrity (Z-IBI) evaluation system using range analysis, discriminant analysis, and correlation analysis. Our research found that these anthropogenic activities can greatly change the composition and number of zooplankton community. The overall health status of this catchment was classified as "good", and the eco-health situation of the reference, industrial, dam-controlled and agricultural sites were deemed "healthy", "fair", "good", and "fair", respectively. Our results suggested that the three activities adversely affected the integrity of local aquatic ecosystems. Agriculture was the activity most detrimental to the zooplankton community, followed by industrial production and dam construction. Therefore, we demonstrated that the Z-IBI evaluation system can be applied to reservoir-riverine ecosystems. We also provide guidance on the ecological protection, assessment, monitoring and of reservoir-riverine ecosystems and suggest that additional Z-IBI evaluation approaches be further developed in the future.
\end{abstract}

Keywords: zooplankton; Z-IBI; industrial production; dam construction; agricultural activities

\section{Introduction}

Bio-integrity refers to the ability of bio-community to adapt to environmental change and maintain structural balance [1]. As early as 1981, Karr [1] used the biological integrity index to assess river health, and since then, this evaluation method has been extensively employed, expanded upon and updated in different hydrobiological groups [2-5]. Biotic indicators such as plants, fish and other animal groups have been used to assess the health of aquatic ecosystems [4,6-8].

As a primary consumer, and a key link in aquatic food chains and webs, zooplankton can affect the community structure of primary producers or consumers through "bottomup" or "top-down" effects, respectively, and its matter cycling and energy flow in the aquatic ecosystem play a key role in both flow and transmission of information [9-11]. Zooplankton are also used to determine changes in the aquatic environment and evaluate the health status of lakes, reservoirs and other water bodies [12,13]. However, few studies have used the zooplankton biological integrity index (Z-IBI) to assess the impacts of industrial activity, dam construction, and agriculture on riverine ecosystems [14]. More research is thus needed on using the Z-IBI to evaluate the ecological health of reservoirriver systems. 
The Wanan Reservoir is the largest reservoir in the Ganjiang River. In recent decades, rapid development has occurred in and around the Wanan River basin which is in the middle reach of the Ganjiang River basin, with the establishment of industrial zones, construction of the dam and production of agricultural goods. However, rapid industrial and economic development also promote the risk of environmental pollution [15]. For instance, persistent pollutants that can harm both wildlife and humans may occur in wastewater resulting from pharmaceutical production, textile printing and dyeing and papermaking [15]. Large hydroelectric projects, while bringing tremendous benefits to people, also cause significant ecological changes. Dam construction drives the transformation of rivers from an estuarine to lacustrine environment and the longitudinal changes in heterogeneity and reservoir residence period [16]. These variations may affect matter cycling [17], water dynamics [18], bio-habitats [19] and river discharge patterns [20]. While both point source and non-point source pollution affect water quality, the latter has been especially problematic during urbanization [21]. Agricultural development has aggravated the amount of non-point source pollution and is thus a significant source of pollution for aquatic ecosystems.

On a global scale, industrial and agricultural activities as well as dam construction have affected the health of aquatic ecosystems in different watersheds. However, their impacts on the biointegrity of aquatic ecosystems remain unclear. In this study, we investigated the variations of the spatial pattern in zooplankton abundance and the composition of the Wanan River basin. The goals of this study were two-fold: to develop a practical Z-IBI system to assess the riverine ecohealth, and to compare Z-IBI scores in areas impressed by industrial activity, dam construction, and agriculture.

\section{Material and Methods}

\subsection{Study Areas}

The Ganjiang River, a great northward-flowing river running through Jiangxi Province, is the largest inflowing river of Lake Poyang (China's largest freshwater wetland), with its main stream length of $823 \mathrm{~km}$. Its drainage area is about $82,809 \mathrm{~km}^{2}$, making it the 7th largest sub-basin in the Yangtze River basin. The Wanan River basin is in the middle reaches of Ganjiang River, and is short for the Wanan reach of the Ganjiang River. The Ganjiang River's largest reservoir, the Wanan Reservoir, located in the upper and middle reaches of the Wanan River basin, and about $50 \%$ of the main stream length was at the upstream of the dam in the Wanan section. The Wanan Reservoir was considered a miniature model of hydraulic engineering (i.e., the Gezhouba Project, which was the first large hydroelectric plant on the Yangtze River, and the Three Gorges Project, which was the largest hydroelectric project in China). The catchment area is $36,900 \mathrm{~km}^{2}$, and lies within the humid climate zone of the mid-subtropical monsoon climate area. The mean annual temperature is $18.5^{\circ} \mathrm{C}$, and the annual precipitation is $1560 \mathrm{~mm}(68.7 \%$ from April to September), with an annual surface water evaporation of approximately $893 \mathrm{~mm}$. The mean annual runoff is 29.7 billion cubic meters. At the downstream of the dam, there are two large tributaries (with totally about 3 billion $\mathrm{m}^{3}$ of annual average runoff amount) and several small tributaries flowing into the main stream in the middle and lower reaches of the Wanan River basin.

A total of 22 sampling points (S1-S22) were chosen and set in the Wanan River basin based on their proximity to industrial zones, dams, and agricultural areas (Figure 1). The industrial zone was $2 \mathrm{~km}$ downstream of the industrial discharge outlet, whereas the agricultural zone was $2 \mathrm{~km}$ downstream of the drainage channel of the farmland and village. The sampling sites of dam areas were less than $20 \mathrm{~km}$ upstream or $40 \mathrm{~km}$ downstream of the dam. The investigation included 3 (S1-S3), 10 (S4-S13), and 6 sampling sites (S14-S19) in areas affected by industrial activity, dam construction, and agriculture. These sampling points were classified as defective. Each impaired point was only affected by one type of human activity (i.e., industrial activity, agriculture, or dam construction). 
Additionally, three sampling sites (S20-S22) in uncontaminated areas were selected as reference points.

The People's Republic of China
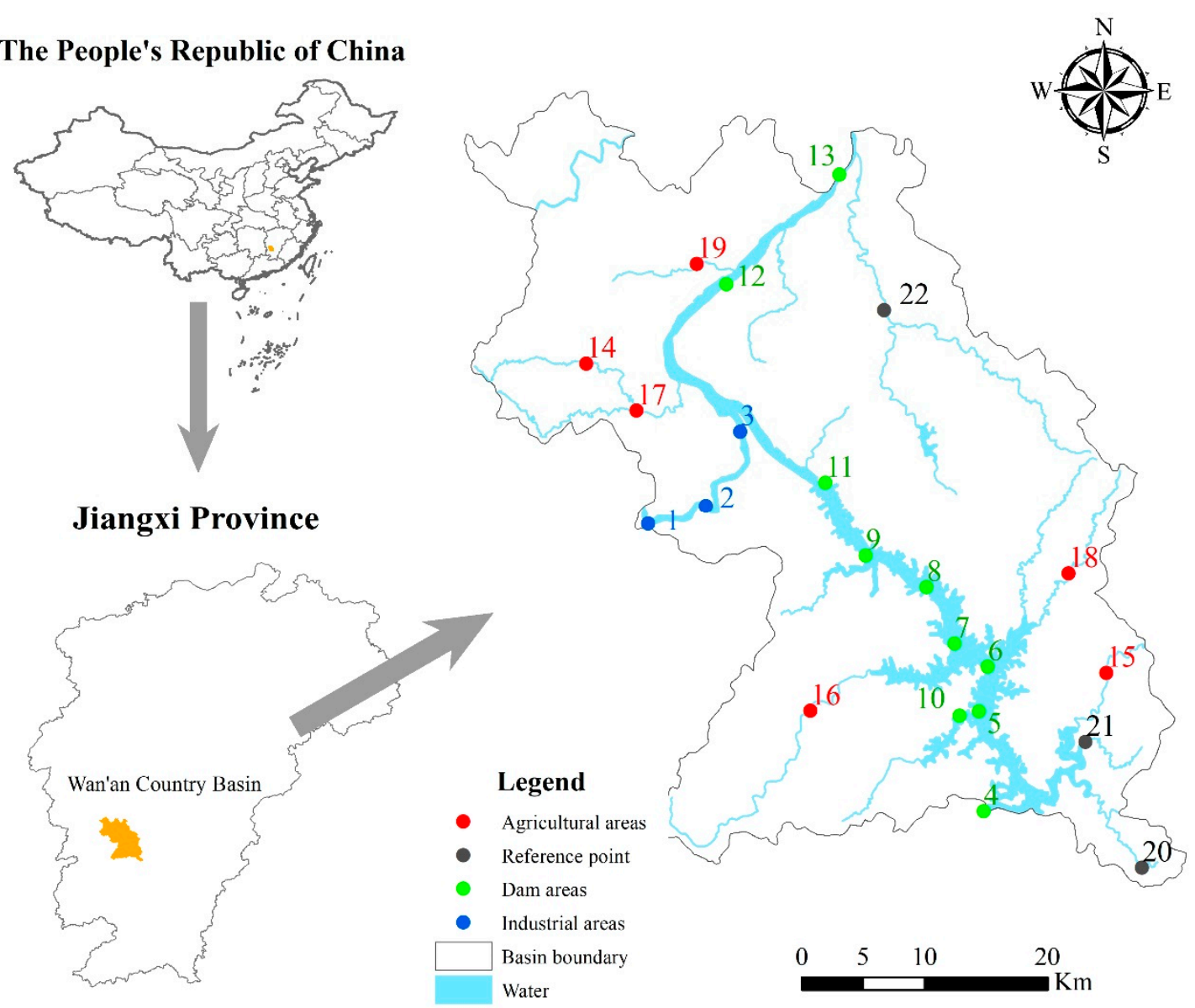

Figure 1. Sampling locations in the Wanan River basin, China.

\subsection{Sampling and Analysis}

Samples were collected once a month from November 2018 to October 2019, excluding July 2019. A 40-L water sample was collected from each site at the upper $(0.5 \mathrm{~m}$ below the water surface), middle (halfway between the surface and the bottom), and lower ( $0.5 \mathrm{~m}$ above the sediment surface) sections of the water column and then pooled together for subsequent analyses of the zooplankton communities. Water samples were sieved through $64-\mu \mathrm{m}$ plankton nets and preserved with $5 \%$ formalin until further analysis [22]. All species in the samples were identified and counted according to Shen et al. [23] and Chiang and Du [24] with a CX33-type Olympus microscope (Olympus Optical Co., Tokyo, Japan).

\subsection{Establishment of Z-IBI Assessment System}

The Z-IBI assessment system was established according to the methods of Sun et al. [25]. There were four types of samples used; three types were from the areas affected by industrial activity (S1-S3), dam construction (S4-S13), and agriculture (S14-S19), and one type was from the reference points (S20-S22). We collected and compiled indicators with a total of 20 attributes that included species density, richness, biomass, and diversity $[26,27]$ (Table 1). 
Table 1. Multiple metrics for calculating the Z-IBI scores in the Wanan River basin, China.

\begin{tabular}{ccc}
\hline Category & Candidate Metrics & Abbreviation \\
\hline \multirow{3}{*}{ Species density } & Total Species density & M1 \\
& Cladocera density & M2 \\
& Copepoda density & M3 \\
& Percentage of Cladocera density & M4 \\
& Percentage of Copepoda density & M5 \\
& Number of total species & M6 \\
Species richness & Number of Cladocera species & M7 \\
& Number of Copepoda species & M8 \\
& Percentage of Cladocera species & M9 \\
& Percentage of Copepoda species & M10 \\
& Total species biomass & M11 \\
& Cladocera biomass & M12 \\
Species biomass & Copepoda biomass & M13 \\
& Percentage of Cladocera biomass & M14 \\
& Percentage of Copepoda biomass & M15 \\
& Number of total individuals & M16 \\
& Dominance Index & M17 \\
Species diversity & Shannon-Wiener index & M18 \\
& Margalef index & M19 \\
& Pielou index & M20 \\
\hline
\end{tabular}

The distribution range, discriminative ability, redundant analysis and Spearman correlation analysis was employed in the selection of biological indicators according to the modified mothed of Feng et al. [28]. We refer to the method of Abdelkefi et al. [29] to readjust the final indicators.

Use Equation (1) to calculate an index that is positively correlated with interference:

$$
\text { Metric value }=(\text { Maximum }- \text { Site value }) /(\text { Maximum }-5 \% \text { quantile })
$$

Use Equation (2) to calculate an index that is negatively correlated with interference:

$$
\text { Metric value }=(\text { Site value } / 95 \% \text { quantile })
$$

The sum of the calculated scores were the final value of Z-IBI. The Z-IBI scores below the lower limit were uniformly divided into four categories (Table 2).

Table 2. The classification standards of eco-health status in the Wanan River basin.

\begin{tabular}{cccccc}
\hline Level & I & II & III & IV & V \\
\hline \multirow{2}{*}{ Health status } & Healthy & Good & Fair & Poor & Extremely poor \\
& $>4.88$ & $3.65-4.88$ & $2.43-3.65$ & $1.22-2.43$ & $\leq 1.22$ \\
\hline
\end{tabular}

Note: The 95\% quantile of the Z-IBI score was considered the lower limit of the "excellent" level among all sampling points. The sampling point with a Z-IBI value greater than the lower limit was considered "healthy" and suffered little human interference.

\subsection{Statistical Analysis}

Statistical analyses (discriminant redundancy test and ability test) for establishing the Z-IBI assessment system were employed in the software of SPSS Version 16.0 (SPSS Inc., Chicago, IL, USA).

In this study, ArcGIS 10.3 (ESRI Inc., Redlands, CA, USA) was used to draw the spatial distribution map and zooplankton integrity of sampling points in the Wanan River Basin [28]. We used Origin 9.1 (OriginLab Corporation, Northampton, MA, USA) to draw the composition, abundance and diversity of zooplankton and Z-IBI values in different areas of the Wanan River Basin. 


\section{Results}

\subsection{Difference in Composition and Structure of Zooplankton Community in Different Regions}

Across all of the sampling sites, 92 species of planktonic crustaceans were identified, including 59 Cladocera and 33 Copepoda in the Wanan River basin (Figure 2). In these studied areas, no significant differences were found in the number of genera (one-way analysis of variance-one-way ANOVA, $p=0.303$ ) (Figure 2a,b).

The mean number of species in the agricultural production waterbodies, industrial zones, dam-controlled waterbodies and the reference areas were 35, 38, 31, and 44, respectively. Cyclopoida and Daphnia were dominant throughout all areas in terms of numbers of genera and species. There were 25 Cladocera species and 13 Copepoda species in areas with agricultural activities, 22 Cladocera species and 9 Copepoda species in areas with industrial activities, 36 Cladocera species and 22 Copepoda species in dam areas and 21 Cladocera and 14 Copepoda species at the reference points (Figure 2c). The numbers of Cladocera species in the agriculture areas, industrial zones, dam-controlled areas, and at the reference points were $60.00,65.79,70.97$, and $62.07 \%$, respectively, and those of Copepoda were 40.00 , $34.21,29.03$, and $37.93 \%$, respectively (Figure 2d). The zooplankton abundances varied substantially in the four-type studied areas (i.e., highest in dam-controlled waterbodies at 25.42 ind. $\mathrm{L}^{-1}$ and lowest in industrial areas at 1.18 ind. $\mathrm{L}^{-1}$; Figure $2 \mathrm{e}$ ). The total density of the zooplankton species across the reservoir-riverine ecosystem was 7.79 ind. $\mathrm{L}^{-1}$. Cladocera and Copepoda were the most abundant in the four areas. In the agricultural areas, industrial zones, dam-controlled waterbodies, and at the reference sites, the respective percentages of Cladocera were 69.37, 75.52, 41.23, and 57.69\%, while those of Copepoda were $30.63,24.48,58.78$, and $42.31 \%$ (Figure $2 \mathrm{f}$ ).
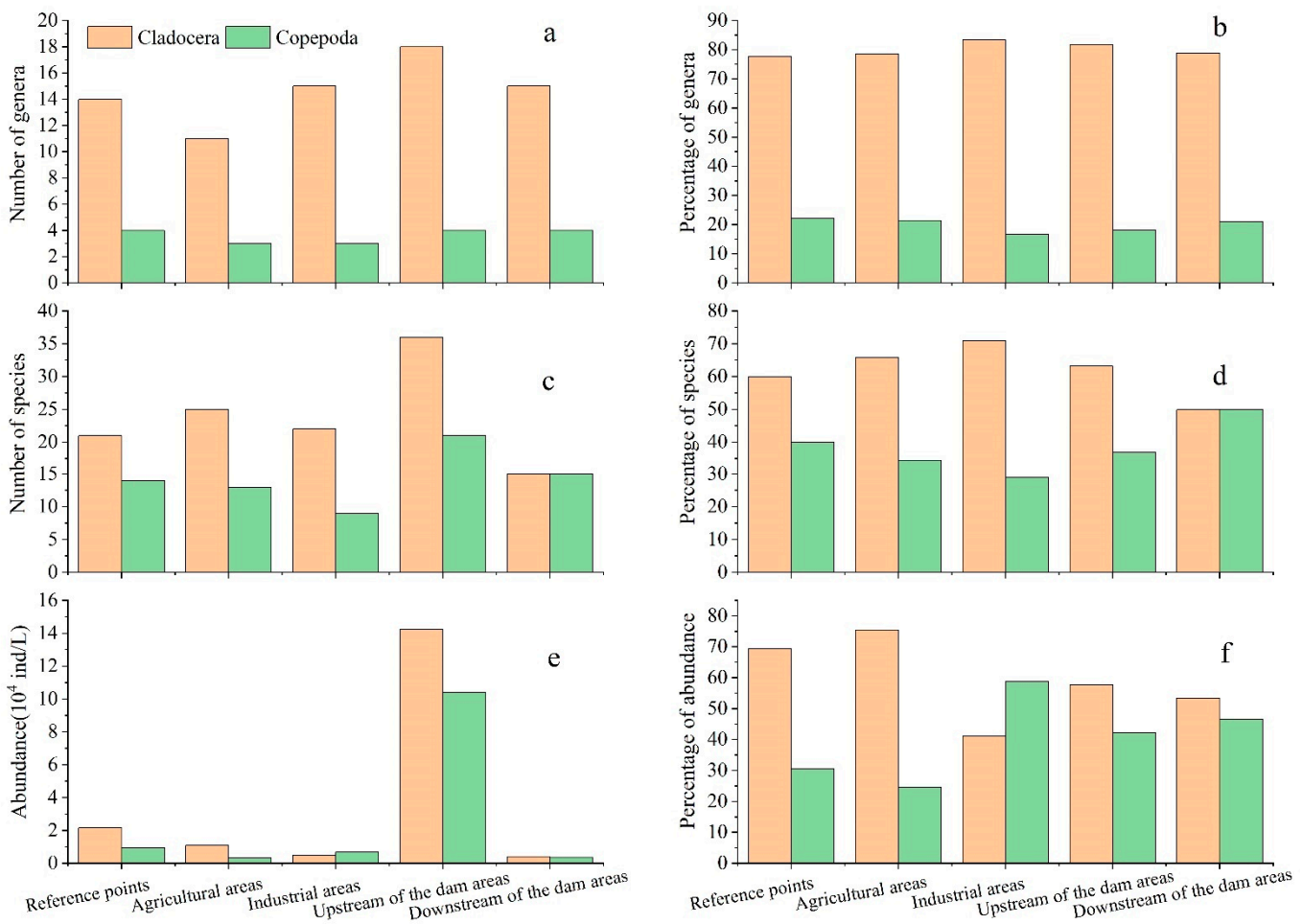

Figure 2. Zooplankton genera, species, abundance, and percentages in different areas of the Wanan River basin, China. (a): Number of Cladocera and Copepoda genera; (b): Percentage of Cladocera and Copepoda genera; (c): Number of Cladocera and Copepoda species; (d): Percentage of Cladocera and Copepoda species; (e): Abundance of Cladocera and Copepoda; (f): Percentage of Cladocera and Copepoda abundance. 


\subsection{Difference of Zooplankton Diversity}

Across the entire basin, the Shannon-Wiener, Pielou, Simpson's dominance, and Margalef index values were 1.46, 0.83, 0.33, and 1.89, respectively (Figure 3). In the industrial zones, the values of these indexes mentioned above were $1.41,0.87,0.34$, and 1.97 , respectively. Upstream of the dam, the values of these diversity indexes above were $1.55,0.75,0.35$, and 1.82 , respectively. Downstream of the dam, the values of these four diversity indexes were $1.69,0.89,0.23$, and 2.19 , respectively. In areas with intensive agriculture, the values of these four diversity indexes were 1.40, 0.86, 0.35, and 1.86, respectively. As for the reference sites, the values of these indexes were 1.24, 0.79, 0.35, and 1.63, respectively. For the Shannon-Wiener, Pielou, and Margalef index, the highest values were found downstream of the dam, and the lowest values in the agricultural areas. Finally, the highest values of Simpson's dominance index occurred upstream of the dam, whereas the lowest values were downstream of the dam.
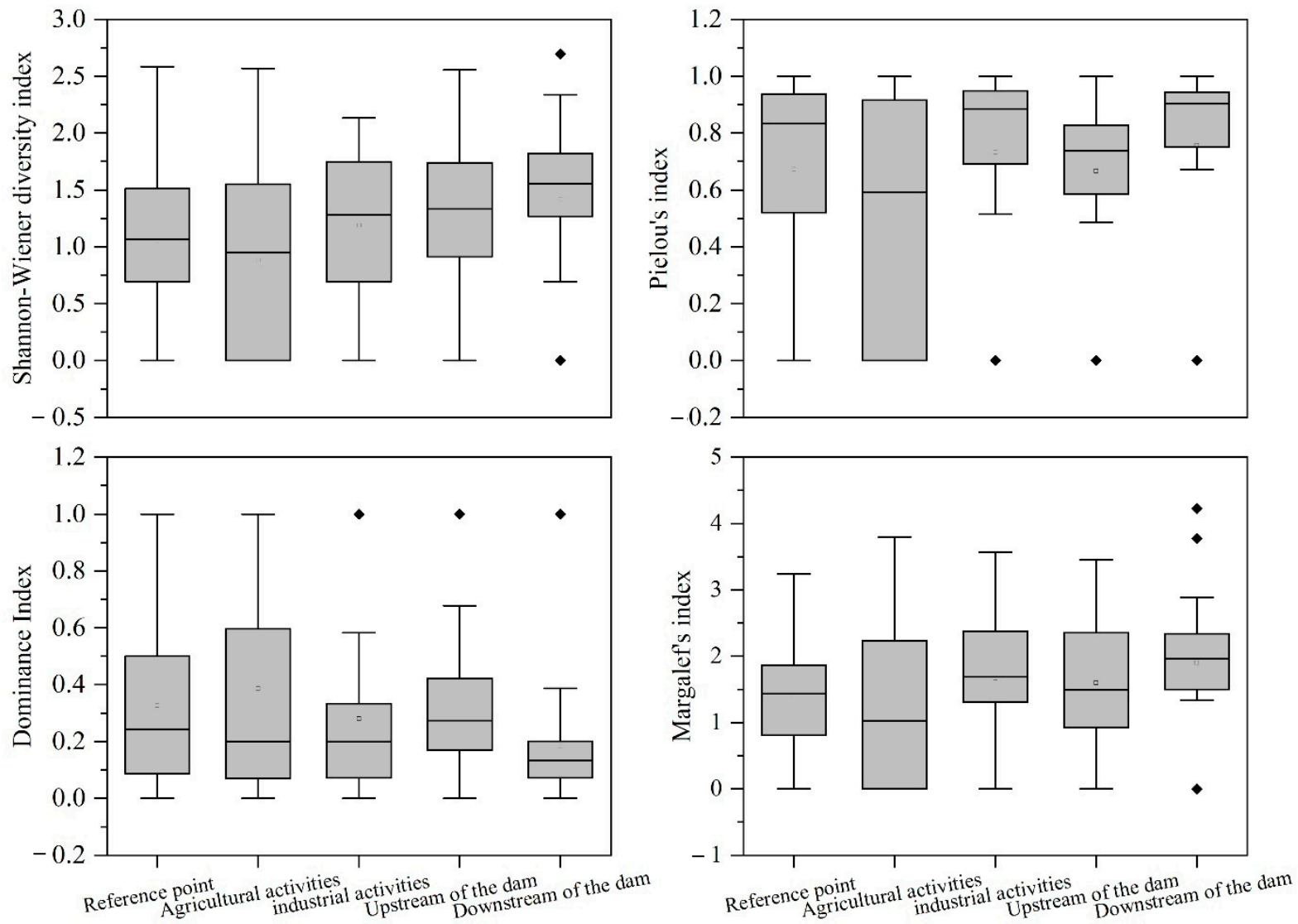

Figure 3. Zooplankton diversity in different areas of the Wanan River basin, China.

\subsection{Z-IBI Evaluation System}

A total of 20 representative candidate species metrics density, richness, biomass and diversity of zooplankton were initially selected to establish the assessment system of Z-IBI (Table 1). Of those, five metrics were found disqualified in the distribution-range test.

According to the results of the box plot analysis, there are 15 metrics that show significant differences between damaged sites(agricultural areas, industrial zones and dam-controlled waterbodies) and the reference ones were considered as the satisfactory indexes for further testing. According to the redundant test results, eight indicators were selected to calculate the Z-IBI value in this study (Figure S1, Table S1). These included: total species density (M1), Cladocera density (M2), percentage of Copepoda density (M5), number of Copepoda species (M8), percentage of Cladocera species (M9), percentage of Copepoda species (M10), the Shannon-Wiener index (M18), and the Pielou index (M20). 


\subsection{Z-IBI Scores of Industrial, Dam-Controlled, and Agricultural Areas and at Reference Sites}

The Z-IBI score of the sampling point were calculated using the ratio method. Since the selected eight metrics were negatively correlated with interference activities, the total species density, percentage of Cladocera density, percentage of Cladocera species, number of Copepoda species, both of Shannon-Wiener and Pielou index, were all calculated by Equation (1). Percentages of Copepoda density and Copepoda species were determined through the method of Equation (2). The 95\% quantile of the Z-IBI scores at all sampling points (4.88) were taken as the lower limit of class I ("healthy"). Z-IBI scores below 4.88 were divided evenly into four different grades: "good" (II), "fair" (III), "poor" (IV), and "extremely poor" (V) (Table 2). The mean Z-IBI score of the Wanan River basin was 4.02 ("good"), and those of the agricultural areas, industrial areas, upstream of dam areas, downstream of dam areas and reference points were 3.11 ("fair"), 3.44 ("fair"), 4.77 ("good"), 3.97 ("good"), and 4.88 ("healthy"), respectively (Figure 4).

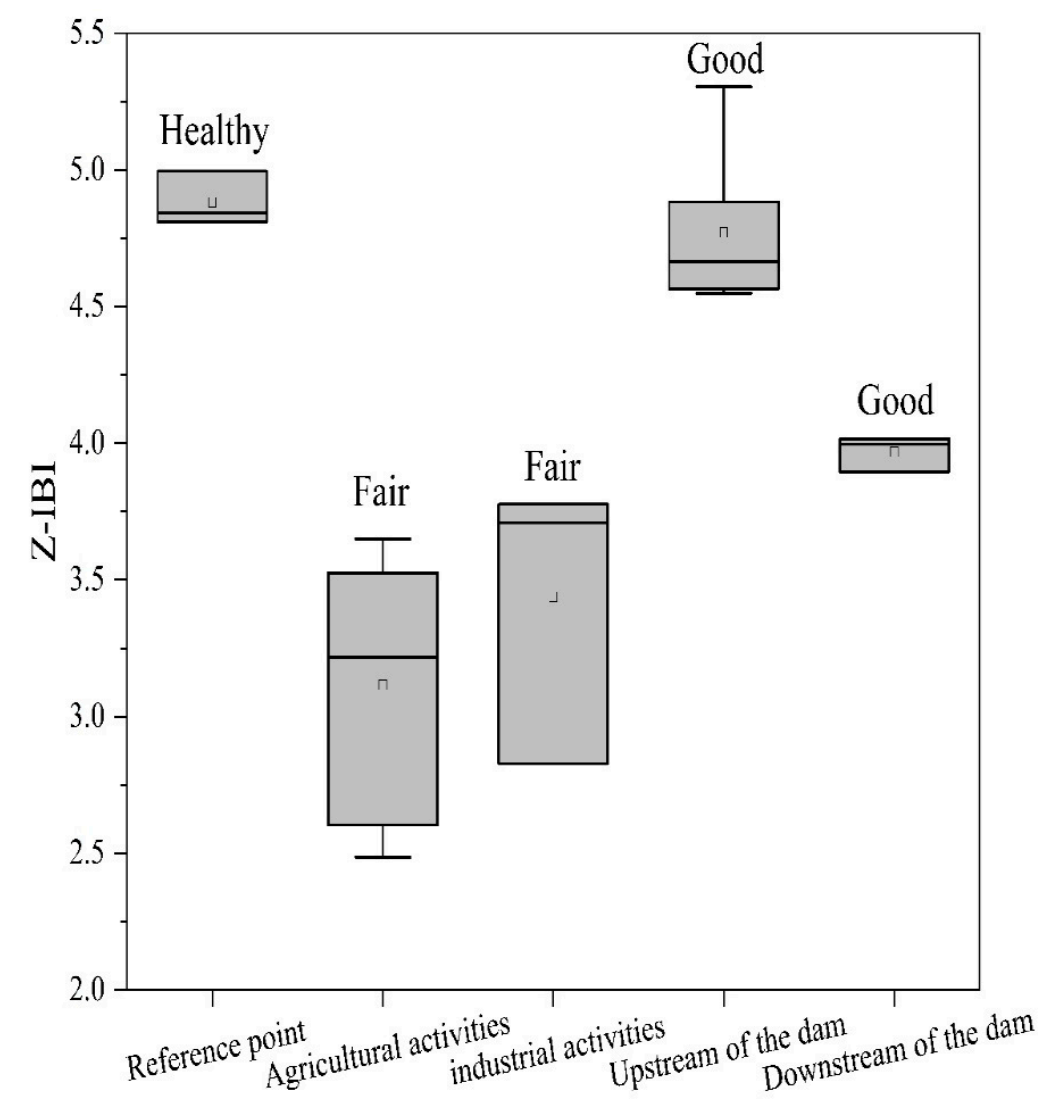

Figure 4. Zooplankton index of bio-integrity (Z-IBI) scores and health status in different areas of the Wanan River basin, China.

Overall, in the Z-IBI aspect, 0, 0, 31.82, 59.09, and 9.09\% of the sampling sites were in terms of health status of "extremely poor", "fair", "good", and "healthy", respectively. Furthermore, $36.84 \%$ of the interference points (industrial zones, dam-controlled waterbody, and agricultural areas) were lower than the eco-health status of "good", and $100 \%$ of the reference points were higher than the eco-health status of "fair" in the Wanan River basin (Figure 5). 


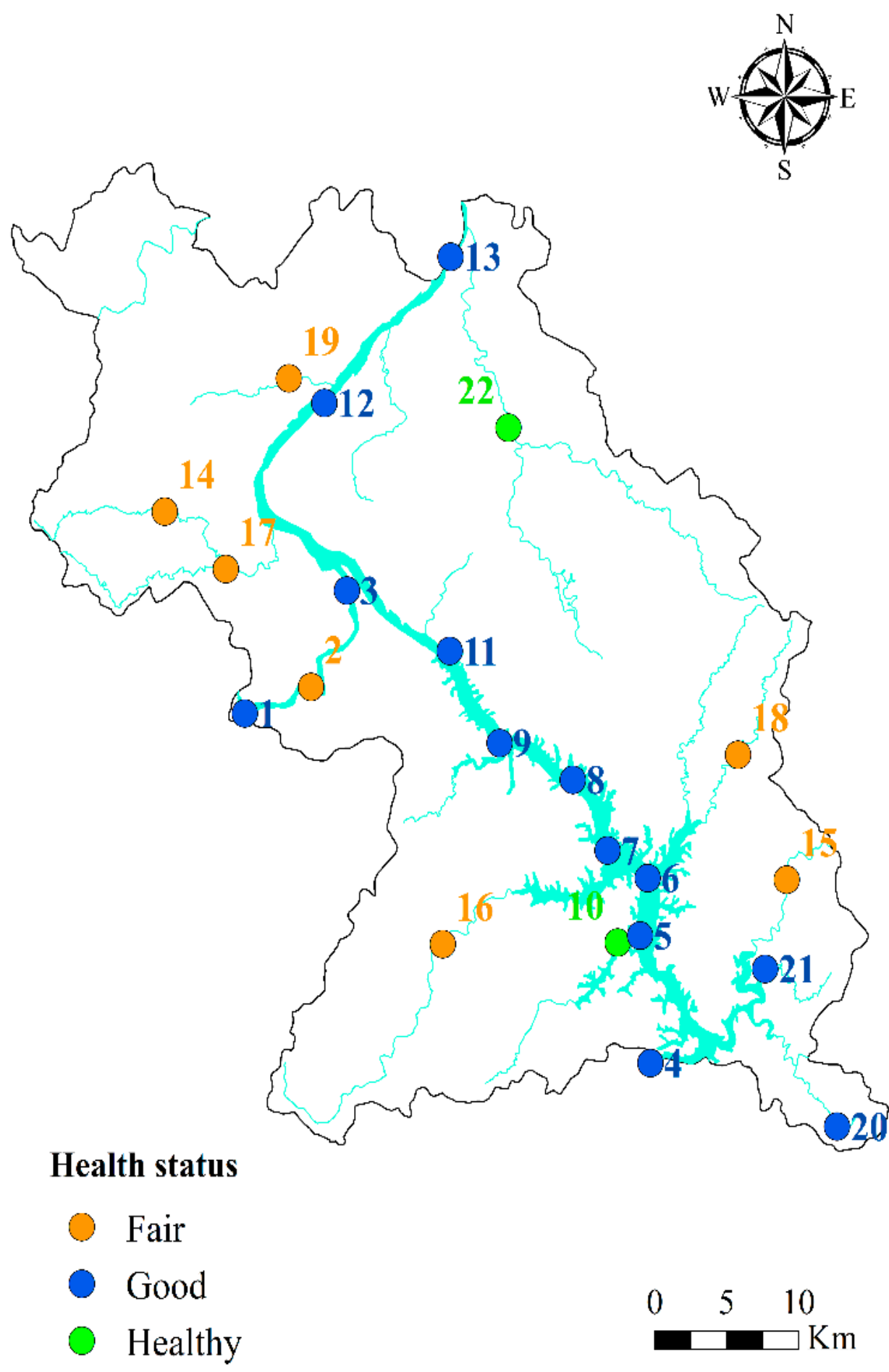

Figure 5. The spatial distribution of Z-IBI values in the Wanan River basin, China.

\section{Discussion}

Zooplankton, including protozoans, rotifers, and microcrustaceans (Cladocerans and Copepods), are often diverse and abundant in most lakes and rivers [30-32]. By accelerating the circulation of nutrients, zooplankton are highly important heterotrophic organisms that play a pivotal role in interactions within the aquatic food web, both as consumers of phytoplankton and as prey of higher trophic-level organisms (e.g., fish and shrimp) $[27,30,33,34]$. As they are typically small with short generation times, zooplankton respond rapidly to changes in local environmental conditions such as water velocity, depth, and retention time [35,36]; therefore, they are well suited for assessing the bio- 
integrity of aquatic systems. The Z-IBI evaluation system was established to digitize and scale the ecological health status of the Wanan River Basin, following the methods of Sun et al. [25]. Our results indicate that the health status of the Wanan River basin is "good". Feng et al. [28] and Chen et al. [37]—who used fish index of bio-integrity, benthic index of bio-integrity, and the planktonic index of bio-integrity, respectively, to assess the eco-health status of the Ganjiang River-found the status of the Ganjiang River to be "fair". Although the Wanan River is midstream of Ganjiang River, it is not the main pollution source of the river.

The health of industrial zones, dam-controlled waterbodies (downstream and upstream of the dam), and agricultural areas were "fair," "good", and "fair,", respectively. Meanwhile, all of the reference points were deemed "healthy" (Figure 4). The spatial distribution of Z-IBI scores also showed that the Z-IBI scores of $89.5 \%$ impaired points (industrial, dam-controlled, and agricultural waterbodies) were less than the scores of the reference sites (Figure 5). This suggests that industrial activities, water dam construction, and intensive agricultural production may disrupt or impair the biotic integrity of the aquatic ecosystem in the Wanan River basin, and thus, the health of reservoir-riverine ecosystems. This is consistent with a report of benthic macroinvertebrate index of biotic integrity (B-IBI) in agricultural and urban-influenced large wetlands [38].

Indeed, increased water consumption owing to industrialization has significantly affected total water resources [39], and industrial discharge will cause a decrease in the quality of freshwater [40], especially by increasing input of oxygen consumption matters. According to the 2018th 'Environment Annual Report of Jiangxi Province', the industrial wastewater discharge in the basin was approximately $3.76 \times 10^{7} \mathrm{t}$. It also shows that the Wanan River Basin has received a large amount of pollutants from industrial activities. The community structure of aquatic organisms is closely related to the aquatic environment, and nutrients (pollution) are considered the key factors for plankton composition and growth $[2,41]$. Indices of biotic integrity (IBIs) show significant reductions when the ecosystems are chemically or physically impaired [38]. Therefore, it is likely that by emitting pollutants, industrial activities could impair the zooplankton community structure, thereby stressing the bio-integrity of this basin. Compared with the reference points, the observed decrease in zooplankton species quantity and abundance in these points of the industrial areas (Figures 2 and 3) supported this conclusion.

Industrial activities and agriculture were associated with changes in zooplankton abundance, but dam construction was not. Compared with reference points, the higher zooplankton species quantity, diversity, and abundance in dam-controlled areas (Figure 2) supported this explanation. Agricultural activities also affected the composition and abundance of the zooplankton community which was similar to industrial activities, as observed here (Figures 2 and 3). The Wanan River basin is an important agricultural production area in Jiangxi Province as well as in China. According to the 2018 'Wanan Annual Report', the annual sown area of grain crops in the Wanan River basin was $440.87 \mathrm{~km}^{2}$, the orchard planting area was $101.4 \mathrm{~km}^{2}$, and the use of pesticides and fertilizers was 16,279 tons; these activities had put great pressure on the surrounding water bodies and had become an important source of pollution in the Wanan River Basin. Dam construction significantly alters the riverine ecosystem by blocking the free flow of the river and creating a semi-lentic or lentic habitat [42-44]. Water quality, habitats, nutrients, sediment transport, and water retention time can be dramatically altered $[45,46]$. The low flow rates and high-water levels caused by dam construction reduce for the diffusion of pollutants, potentially resulting in high concentration of pollutants in local waterbodies and creating severe environmental consequences [47]. This may make clear why dam construction damages bio-integrity or the eco-health of the riverine ecosystems. According to our results, the concentrations of total nitrogen $(\mathrm{TN})$ and total phosphorus (TP) in the surface water of agricultural activity areas were $0.96-2.50 \mathrm{mg} / \mathrm{L}$ (Grade III in National environmental quality standard of surface water of China GB 3838-2002: $1.0 \mathrm{mg} / \mathrm{L}$ ) and $0.05-0.20 \mathrm{mg} / \mathrm{L}$ (Grade III: $0.2 \mathrm{mg} / \mathrm{L}$ for river, $0.05 \mathrm{mg} / \mathrm{L}$ for reservoir and lake), respectively. A large amount of nutrients caused 
the river's nutrient concentrations to rise and weakened the integrity of the zooplankton. Indeed, previous studies have shown that agriculture has a negative impact on freshwater ecosystems [48]. Hegde et al. [49] found that the presence of both malathion and fertilizer cut down on zooplankton density and diversity. Here, the Z-IBI scores of both industrial zones and dam-controlled areas were both higher than those in agricultural production waterbodies (Figure 4). It indicates that, over the long term, agricultural activities may be more harmful to zooplankton communities and the health of river ecosystems than light industrial production or dam construction. Similarly, Zhu et al. [5] observed that the health of wetlands-as assessed by a microbial community-based index of biotic integrity (MCIBI) - was the lowest at the inflows of wetlands receiving agricultural effluent compared with those receiving industrial and urban effluent.

\section{Conclusions}

In this study, we developed the Z-IBI system to digitize and scale the impact of industrial production, dam construction and agriculture on the bio-integrity of the aquatic ecosystem in the Wanan River basin. Industrial activities and agriculture-but not dam construction - affected the abundance of zooplankton community. The eco-health of the river was overall "good", and the eco-health statuses were "fair", "good", "fair", and "healthy" in the industrial, dam-controlled, agricultural waterbodies, and reference sites, respectively. Industrial activities, dam construction and agricultural production damaged the biotic integrity of aquatic systems. Moreover, compared with industrial activities and dam construction, agriculture was more harmful to zooplankton. We conclude that the Z-IBI is a useful way of measuring the health of aquatic ecosystems, and by extrapolation, the health of the reservoir-riverine ecosystem.

Supplementary Materials: The following are available online at https:/ / www.mdpi.com/2073-444 1/13/2/123/s1, Figure S1: Multiple metrics in different areas of the Wanan River basin, China; Table S1 Multiple metrics correlation in different areas of the Wanan River basin, China.

Author Contributions: Data curation, N.Y., B.F. and Z.L.; Investigation, L.H. and H.Z.; Methodology, B.F.; Resources, Z.L.; Writing—original draft, N.Y., B. F. and M.Z.; Writing—review \& editing, N.Y. All authors have read and agreed to the published version of the manuscript.

Funding: This work was supported by the Major Discipline Academic and Technical Leaders Training Program of Jiangxi Province (20182BCB22016) and the Key R\&D Projects in Jiangxi Province (20161BBG70098)

Institutional Review Board Statement: Not applicable.

Informed Consent Statement: Informed consent was obtained from all subjects involved in the study.

Data Availability Statement: All researchers involved approve the availability of the data.

Acknowledgments: We are grateful to Binghao Wan, Qipei Wang, Linkai Hu, Yanli Shi, Nina Xiao, Qingqing Cheng, and Mingri Xiong in Jiangxi Academy of Environmental Sciences for their help with field sampling.

Conflicts of Interest: We declare that we have no financial and personal relationships with other people or organizations that can inappropriately influence our work, and there is no professional or other personal interest of any nature or kind in any product, service, or company that could be construed as influencing the position presented in, or the review of, the manuscript entitled-Impact of Industrial Production, Dam Construction and Agriculture on the Z-IBI in River Ecosystems: A Case Study of the Wanan River Basin, China.

\section{References}

1. Karr, J.R. Assessment of Biotic Integrity Using Fish Communities. Fisheries 1981, 6, 21-27. [CrossRef]

2. Wu, N.; Cai, Q.; Fohrer, N. Development and evaluation of a diatom-based index of biotic integrity (D-IBI) for rivers impacted by run-of-river dams. Ecol. Indic. 2012, 18, 108-117. [CrossRef] 
3. Cui, W.Y.; Guo, S.Y.; Meng, X.Z.; Kong, F.Q. Application of adapted Benthic Index of Biotic Integrity (B-IBI) for river ecosystem health assessment in Zhanghe River Watershed, China. Pol. J. Ecol. 2019, 66, 407-415. [CrossRef]

4. Pomari, J.; Kane, D.D.; Ferreira, R.A.R.; Nogueira, M.G. A new tool to assess ecosystem health in large subtropical reservoirs: Development and validation of a Planktonic Index of Biotic Integrity. Aquat. Ecosyst. Health Manag. 2019, 22, 15-29. [CrossRef]

5. Zhu, W.T.; Liu, Y.Y.; Wang, S.; Yu, M.; Qian, W. Development of microbial community-based index of biotic integrity to evaluate the wetland ecosystem health in Suzhou, China. Environ. Monit. Assess. 2019, 191, 377. [CrossRef] [PubMed]

6. Xu, X.Q.; Cai, W.Q.; Lei, K.; Yin, X.W.; Han, J.; Sun, M.D. Assessment on Ecological Integrity of Rivers in Tianjin City. Res. Environ. Sci. 2020, 33, 2308-2317, (In Chinese with English Abstract). [CrossRef]

7. Wang, Z.; Zhao, W.; Wei, J.; Li, B.; Shi, X.; Wang, T.Y.; Dong, C.H.; Yin, D.P. Plankton Community Structure and Eutrophication Evaluation in Lake Junhai, Beijing. J. Biol. 2020. Available online: https://kns.cnki.net/kcms/detail/34.1081.Q.20200616.0914.00 4.html (accessed on 7 June 2020). (In Chinese with English Abstract).

8. Liu, L.F.; Xu, Z.X.; Yin, X.W.; Li, F.L.; Wang, M. Assessment of the Water Quality in Jinan City by Using both Fish and BenthicMacroinvertebrate Index of Biotic Integrity. Res. Environ. Sci. 2019, 8, 1134-1394. (In Chinese with English Abstract)

9. Xiong, W.; Ni, P.; Chen, Y.Y.; Gao, Y.C.; Shan, B.Q.; Zhan, A.B. Zooplankton community structure along a pollution gradient at fine geographical scales in river ecosystems: The importance of species sorting over dispersal. Mol. Ecol. 2017, 26, 4351-4360. [CrossRef] [PubMed]

10. Liu, P.; Xu, S.; Lin, J.; Li, H.; Lin, Q.; Han, B.-P. Urbanization increases biotic homogenization of zooplankton communities in tropical reservoirs. Ecol. Indic. 2019, 110, 105899. [CrossRef]

11. Ye, L.; Chang, C.Y.; García-Comas, C.; Gong, G.C.; Hsieh, C.H. Increasing zooplankton size diversity enhances the strength of top-down control on phytoplankton through diet niche partitioning. J. Anim. Ecol. 2013, 82, 1052-1060. [CrossRef]

12. Stamou, G.; Katsiapi, M.; Moustaka-Gouni, M.; Michaloudi, E. Trophic state assessment based on zooplankton communities in Mediterranean lakes. Hydrobiologia 2019, 844, 83-103. [CrossRef]

13. Yao, C.; He, T.R.; Xu, Y.Y.; Ran, S.; Qian, X.L.; Long, S.X. Mercury bioaccumulation in zooplankton and its relationship with eutrophication in the waters in the karst region of Guizhou Province, southwest China. Environ. Sci. Pollut. Res. 2020, 27, 8596-8610. [CrossRef] [PubMed]

14. Zhou, S.C.; Tang, T.; Wu, N.C.; Fu, X.C.; Cai, Q.H. Impacts of a small dam on riverine zooplankton. Int. Rev. Hydrobiol. 2008, 93, 297-311. [CrossRef]

15. Mao, Y.; Yang, S.; Xue, C.; Zhang, M.M.; Wang, W.L.; Song, Z.L.; Zhao, X.Q.; Sun, J. Rapid degradation of malachite green by $\mathrm{CoFe}_{2} \mathrm{O}_{4}$-SiC foam under microwave radiation. R. Soc. Open Sci. 2018, 5, 180085. [CrossRef] [PubMed]

16. Moitra, M.; Leff, L.G. Bacterial community composition and function along a river to reservoir transition. Hydrobiologia 2015, 747, 201-215. [CrossRef]

17. Shiyomi, M.; Takahashi, S.; Kirita, H. Roles of plant biomass and vegetational heterogeneity, and energy-matter cycling in grassland sustainability. Ecol. Model. 2000, 132, 135-149. [CrossRef]

18. Kornis, M.S.; Weidel, B.C.; Powers, S.M.; Diebel, M.W.; Cline, T.J.; Fox, J.M.; Kitchell, J.F. Fish community dynamics following dam removal in a fragmented agricultural stream. Aquat. Sci. 2015, 77, 465-480. [CrossRef]

19. Poff, N.L.; Olden, J.D. Can dams be designed for sustainability? Science 2017, 358, 1252-1253. [CrossRef]

20. Keefer, M.L.; Peery, C.A.; Caudill, C.C. Migration Timing of Columbia River Spring Chinook Salmon: Effects of Temperature, River Discharge, and Ocean Environment. Trans. Am. Fish. Soc. 2008, 137, 1120-1133. [CrossRef]

21. Qiu, Z.; Walter, M.T.; Hall, C. Managing variable source pollution in agricultural watersheds. J. Soil Water Conserv. 2007, 62, 115-122.

22. Huang, X.F.; Chen, W.M.; Cai, Q.M. Survey, observation and analysis of lake ecology. In Standard Methods for Observation and Analysis in Chinese Ecosystem Research Network; Series V; Standards Press of China: Beijing, China, 2000. (In Chinese)

23. Shen, J.; Tai, A.; Zhang, C.; Li, Z.; Song, D.; Chen, G. Fauna Sinica, Crustacea, Freshwater Copepod; Institute of Zoology, Academia Sinica: Beijing, China, 1979. (In Chinese)

24. Chiang, S.C.; Du, N.S. Fauna Sinica, Crustacea: Freshwater Cladocera; Science Press, Academia Sinica: Beijing, China, 1979. (In Chinese)

25. Sun, Y.K.; Yang, G.; Li, C.L.; Wang, N. Establishment of zooplankton index of biotic integrity for Jiaozhou Bay. Mar. Sci. 2015, 39, $1-7$.

26. Rutherford, S.; D'Hondt, S.; Prell, W. Environmental controls on the geographic distribution of zooplankton diversity. Nature 1999, 400, 749-753. [CrossRef]

27. Li, X.; Yu, Y.; Li, C.; Yan, Q. Comparative study on the gut microbiotas of four economically important Asian carp species. Sci. China Life Sci. 2018, 61, 696-705, (In Chinese with English Abstract). [CrossRef] [PubMed]

28. Feng, B.; Zhang, M.; Chen, J.F.; Xu, J.; Xiao, B.D.; Zhou, M.; Zhang, M. Reduction in the phytoplankton index of biotic integrity in riverine ecosystems driven by industrial activities, dam construction and mining: A case study in the Ganjiang River, China. Ecol. Indic. 2021, 120, 106907. [CrossRef]

29. Abdelkefi, A.; Vasconcellos, R.; Nayfeh, A.H.; Hajj, M.R.; Badran, O. Nonlinear Analysis and Identification of Limit Cycle Oscillations in an Aeroelastic System. In Proceedings of the 53rd AIAA/ASME/ASCE/AHS/ASC Structures, Structural Dynamics \& Materials Conference, Honolulu, HI, USA, 23-26 April 2012.

30. Allan, J.D. Life history patterns in zooplankton. Am. Nat. 1976, 110, 165-180. [CrossRef] 
31. Kobayashi, T.; Shiel, R.J.; Gibbs, P.; Dixon, P.I. Freshwater zooplankton in the Hawkesbury-Nepean River: Comparison of community structure with other rivers. Hydrobiologia 1998, 377, 133-145. [CrossRef]

32. Luo, X.T.; Gao, F.; Yi, Z.Z.; Pan, Y.; Al-Farraj, S.A.; Warren, A. Taxonomy and molecular phylogeny of two new brackish hypotrichous ciliates, with the establishment of a new genus (Ciliophora, Spirotrichea). Zool. J. Linn. Soc. 2017, 179, 475-491.

33. Cooper, S.D.; Goldman, C.R. Opossum shrimp (Mysis relicta) predation on zooplankton. Can. J. Fish. Aquat. Sci. 1980, 37, 909-919. [CrossRef]

34. Domingues, C.D.; Silva, L.H.S.; Rangel, L.M.; Magalhães, L.; Rocha, A.; Lobão, L.M.; Paiva, R.; Roland, F.; Sarmento, H. Microbial food-web drivers in tropical reservoirs. Microb. Ecol. 2017, 73, 505-520. [CrossRef] [PubMed]

35. Havel, J.E.; Medley, K.A.; Dickerson, K.D.; Angradi, T.R.; Bolgrien, D.W.; Bukaveckas, P.A.; Jicha, T.M. Effect of main-stem dams on zooplankton communities of the Missouri River (USA). Hydrobiologia 2009, 628, 121-135. [CrossRef]

36. Liu, W.; Jiang, J.; Xu, Y.; Pan, X.; Qu, Z.; Luo, X.; El-Serehy, H.A.; Warren, A.; Ma, H.; Pan, H. Diversity of free-living marine ciliates (Alveolata, Ciliophora): Faunal studies in coastal waters of China during the years 2011-2016. Eur. J. Protistol. 2017, 61, 424-438. [CrossRef] [PubMed]

37. Chen, H.W.; Zhang, M.; Liu, Z.G.; Zhang, Z.; Fang, H.Y. Assessment on freshwater ecosystem integrity and health in Ganjiang River basin through the fish IBI method. Resour. Environ. Yangtze Basin 2011, 20, 1098-1107, (In Chinese with English Abstract).

38. Gernes, M.C.; Helgen, J.C. Indexes of Biological Integrity (IBI) for Large Depressional Wetlands in Minnesota; Minnesota Pollution Control Agency: St. Paul, MN, USA, 2002.

39. Kummu, M.; Guillaume, J.H.A.; Moel, H.D.; Eisner, S.; Flörke, M.; Porkka, M.; Siebert, S.; Veldkamp, T.I.E.; Ward, P.J. The world's road to water scarcity: Shortage and stress in the 20th century and pathways towards sustainability. Sci. Rep. 2016, 6, 38495. [CrossRef] [PubMed]

40. Ludwig, F.; van Slobbe, E.; Cofino, W. Climate change adaptation and Integrated Water Resource Management in the water sector. J. Hydrol. 2014, 518 Pt B, 235-242. [CrossRef]

41. Jeppesen, E.; Nõges, P.; Davidson, T.A.; Haberman, J.; Nõges, T.; Blank, K.; Lauridsen, T.L.; Søndergaard, M.; Sayer, C.; Laugaste, R.; et al. Zooplankton as indicators in lakes: A scientific-based plea for including zooplankton in the ecological quality assessment of lakes according to the European Water Framework Directive (WFD). Hydrobiologia 2011, 676, 279-297. [CrossRef]

42. Silva, L.H.S.; Huszar, V.L.M.; Marinho, M.M.; Rangel, L.M.; Brasil, J.; Domingues, C.D.; Branco, C.C.; Roland, F. Drivers of phytoplankton, bacterioplankton, and zooplankton carbon biomass in tropical hydroelectric reservoirs. Limnologica 2014, 48, 1-10. [CrossRef]

43. Oliveira, A.G.; Baumgartner, M.T.; Gomes, L.C.; Dias, R.M.; Agostinho, A.A. Long-term effects of flow regulation by dams simplify fish functional diversity. Freshw. Biol. 2018, 63, 293-305. [CrossRef]

44. Baxter, R.M. Environmental effects of dams and impoundments. Annu. Rev. Ecol. Syst. 1977, 8, 255-283. [CrossRef]

45. Baumgartner, M.T.; Baumgartner, G.; Gomes, L.C. The effects of rapid water level changes on fish assemblages: The case of a spillway gate collapse in a Neotropical reservoir. River Res. Appl. 2017, 33, 548-557.

46. Loken, L.C.; Crawford, J.T.; Dornblaser, M.M.; Striegl, R.G.; Houser, J.N.; Turner, P.A.; Stanley, E.H. Limited nitrate retention capacity in the Upper Mississippi River. Environ. Res. Lett. 2018, 13, 074030. [CrossRef]

47. Lin, Q. Influence of Dams on River Ecosystem and Its Countermeasures. J. Water Resour. Prot. 2011, 3, 60-66. [CrossRef]

48. Miracle, M.R.; Alfonso, M.T.; Vicente, E. Fish and nutrient enrichment effects on rotifers in a Mediterranean shallow lake: A mesocosm experiment. Hydrobiologia 2007, 593, 77-94. [CrossRef]

49. Hegde, G.; Mandya, M.; Gokarnakar, S.S.; Babu, V.N.; Shivaramaiah, V.N.; Krishnamurthy, S.V. Influence of combinations of pesticides and fertilizers on aquatic productivity. J. Environ. Prot. 2014, 5, 434-440. [CrossRef] 